\title{
Hubungan Karakteristik Demografi dan Resiliensi Mahasiswa Keperawatan yang Sedang Mengerjakan Skripsi
}

\author{
Ammi Salamah, Suryani, Windy Rakhmawati \\ Fakultas Keperawatan, Universitas Padjadjaran, Bandung \\ email: ammi15001@mail.unpad.ac.id
}

\begin{abstract}
Abstrak
Artikel INFO

Diterima:31 Mei 2020

Direvisi :03 Sep 2020

Disetujui: 11 Nov 2020

DOI:

http://dx.doi.org/10.24014/

jp.v14i2.9835

Beratnya beban studi mahasiswa keperawatan dapat berdampak pada waktu yang diperlukan untuk menyelesaikan studi. Mengerjakan skripsi memiliki beban studi tinggi dan berbeda dengan mata kuliah lain, sehingga resiliensi yang lebih tinggi dibutuhkan untuk menghadapi kesulitan saat mengerjakan skripsi. Penelitian ini bertujuan mengetahui hubungan antara karakteristik demografi dan resiliensi mahasiswa keperawatan yang sedang mengerjakan skripsi. Penelitian ini menggunakan metode deskriptif korelasional. Penelitian melibatkan 329 mahasiswa keperawatan yang sedang mengerjakan skripsi. Pengukuran resiliensi menggunakan kuesioner Connor Davidson Resilience Scale 25. Analisa data menggunakan analisis univariat dan bivariat. Hasil penelitian menunjukkan rata-rata karakteristik resiliensi lebih tinggi terjadi pada dewasa awal, laki-laki, beragama Kristen, berasal dari Jawa Barat dengan budaya Sunda, berstatus ekonomi tinggi, dan belum menikah. Adapun pada uji korelasi menggunakan chi-square $(\alpha=0.05)$ didapatkan status ekonomi berkorelasi dengan resiliensi mahasiswa keperawatan yang sedang mengerjakan skripsi $(\rho=0.014)$. Berdasarkan hasil temuan, ditunjukkan bahwa resiliensi mahasiswa keperawatan yang sedang mengerjakan skripsi dapat ditentukan oleh faktor demografi dan secara signifikan berkolerasi dengan status ekonomi.
\end{abstract}

Kata-kata kunci: karakteristik demografi, mahasiswa keperawatan, resiliensi, skripsi.

\section{Relationship Between Demographic Characteristics and Nursing Students' Resilience Working on Bachelor Thesis}

\begin{abstract}
The weight of nursing students study load can have an impact on the time needed to complete the study. Bachelor thesis work has a high study load and is different from other subjects, so higher resilience is needed to face difficulties when working on bachelor thesis. The purpose of the study is to determine the relationship between demographic characteristics and the resilience of nursing students working on bachelor thesis. The study used a correlational descriptive design. The study involved 329 students nursing students who were working on bachelor thesis. Resilience measurement used the Connor Davidson Resilience Scale 25 questionnaire. Data was analyzed using univariate and bivariate analysis. The research showed that the higher resilience characteristics mean occurred in early adulthood, male, Christian, from West Java with Sundanese culture, high economic status, and unmarried. As for the correlation test using chi-square correlation $(\alpha=0.05)$, It was found that that economic status correlated with the resilience of nursing students $(\rho=0.014)$. Based on the findings, it is showed that the resilience of nursing students can be determined by a number of demographic factors and showed significant correlation with economy status.
\end{abstract}

Keywords: bachelor thesis, demographic characteristics, nursing students, resilience.

\section{Pendahuluan}

Mahasiswa dalam mengerjakan skripsi menemui berbagai masalah yang dapat menghambat mereka dalam mengerjakan skripsi. Tidak jarang, hambatan dalam mengerjakan skripsi sekaligus dapat menunda waktu kelulusan. Sudah banyak penelitian terkait hambatan mahasiswa dalam mengerjakan skripsi. Hambatan tersebut dapat bersumber dari diri sendiri maupun dari luar. Hambatan-hambatan tersebut seperti motivasi mahasiswa yang rendah untuk lulus tepat waktu, kemampuan dalam menulis skripsi, serta perasaan cemas 
dan takut seperti tidak dapat mengerjakan skripsi ataupun menganggap skripsi sebagai tugas yang sulit/menakutkan (Agung \& Budiani, 2013; Asmawan, 2016; Aziz \& Rahardjo, 2013). Selain itu, sulit menemui dosen pembimbing, keterbatasan sarana dan prasana penelitian, dan terbatasnya waktu penelitian juga dapat menjadi penghambat mahasiswa dalam mengerjakan skripsi (Agung \& Budiani, 2013; Yulia, Afrianti, \& Octaviani, 2015).

Tidak hanya faktor-faktor penghambat, resiliensi mahasiswa pun turut berkontribusi pada keberhasilan/kegagalan mahasiswa dalam menghadapi kesulitan/masalah yang menimbulkan stres/tekanan selama mengerjakan skripsi. Di mana dengan resiliensi, seseorang yang sedang menghadapi kesulitan dapat mengatasi stres/ tekanan yang ditimbulkannya (Connor \& Davidson, 2003; Greene, Galambos, \& Lee, 2004). Selain itu, resiliensi juga dikaitkan dengan kemampuan untuk beradaptasi dan bangkit kembali dalam menghadapi suatu kesulitan (Windle, 2011). Menurut Southwick, Bonanno, Masten, Panter Brick, dan Yehuda (2014), resiliensi memungkinkan seseorang untuk menggunakan berbagai strategi penanggulangan masalah untuk bergerak maju dan berhasil beradaptasi dengan suatu kesulitan. Artinya, dengan resiliensi juga, mahasiswa bisa mengatasi kesulitan dan mendapatkan hasil yang baik setelah melewati kesulitan dalam mengerjakan skripsi seperti berhasil menyelesaikan skripsi tepat waktu.

Pada studi pendahuluan di salah satu Fakultas Keperawatan di Jawa Barat [X], jumlah mahasiswa yang berhasil menyelesaikan skripsi tepat waktu terus menurun dalam lima tahun terakhir (20142018) yaitu dari $84 \%$ turun menjadi $37 \%$. Didapatkan juga data, bahwa mahasiswa yang terlambat lulus seluruhnya dikarenakan skripsi yang belum selesai atau mahasiswa yang sudah enggan mengerjakan skripsi. Selain itu, kesadaran mahasiswa keperawatan $\mathrm{X}$ untuk mengkonsultasikan kesulitan saat mengerjakan skripsi pada Tim Pelayanan dan Bimbingan Konseling (TPBK) Fakultas atau dosen wali pun rendah. Hal ini mengindikasikan bahwa mahasiswa keperawatan $\mathrm{X}$ menemui kesulitan akademik terutama dalam mengerjakan skripsi serta belum optimal dalam memanfaatkan layanan TPBK dan pertemuan dengan dosen wali. Padahal peran lembaga dalam hal pengasuhan dapat mengajarkan resiliensi dan memerankan peran penting dalam hal dukungan sosial (Greene et al., 2004), di mana peran tersebut diantaranya diperankan oleh TPBK dan dosen wali. Apabila mahasiswa dapat memanfaatkan fungsi TPBK/dosen wali dengan optimal, mereka bisa mendapatkan penguatan rasa percaya diri yang dapat menjadi sumber dukungan dan motivasi terutama bagi mahasiswa yang sedang mengerjakan skripsi. Hal ini didukung dalam beberapa penelitian sebelumnya yang mendapatkan hasil bahwa dukungan sosial dapat meningkatkan resiliensi mahasiswa yang sedang mengerjakan skripsi (Mufidah, 2017; Sari \& Indrawati, 2016).

Terlepas dari aspek-aspek resiliensi, resiliensi juga dapat dipengaruhi oleh karakteristik demografi (Bonanno, Westphal, \& Mancini, 2010; Connor \& Davidson, 2003). Di mana pada penelitian Bonanno et al., (2010) dijelaskan karakteritik demografi pada laki-laki, usia lebih tua, dan pendidikan yang lebih baik menunjukkan resiliensi yang lebih tinggi. Ras/etnis pun memberikan hasil resiliensi yang berbeda dan berkaitan dengan status ekonomi-sosial (Bonanno et al., 2010). Adapun menurut Connor dan Davidson (2003) demografi pada suatu kelompok akan menghasilkan skor tingkat resiliensi yang berbeda dengan kelompok lain (Connor \& Davidson, 2003). Hal ini menunjukkan karakteristik demografi yang berbebeda akan memberikan tingkatan resiliensi yang bervariasi. Sama halnya dengan yang 
terjadi pada resiliensi mahasiswa, demografi pun dapat mempengaruhi tingkat resiliensi mahasiswa, sehingga tingkatan resiliensi yang dimiliki pun akan bervariasi. Adapun karakteristik-karakteristik demografi yang pernah diteliti pada resiliensi mahasiswa diantaranya adalah jenis kelamin, budaya, dan agama (Amelia, Asni \& Chairilsyah, 2014; Azzahra, 2017; Cahyani \& Akmal, 2017; Mufidah, 2017; Prihartono, Sutini, \& Widianti, 2018; Roellyana \& Listiyandini, 2016; Willda, Nazriati, \& Firdaus, 2016) Pada penelitianpenelitian tersebut ditunjukkan adanya salah satu kelompok berdasarkan karakteristik demografi tersebut yang lebih resilien.

Pada budaya, budaya memiliki pengaruh terhadap resiliensi melalui adanya dukungan sosial. Dimana dukungan sosial meliputi pengaruh komunitas dan budaya, sekolah, diri sendiri, dan dukungan keluarga (Holaday \& McPhearson, 1997). Hal ini menunjukkan latar belakang budaya mahasiswa keperawatan yang berbeda dengan lingkungan tempat tinggalbarunyamenempuhstudikeperawatan, kehadiran/ketersediaan komunitas budaya, hubungan dengan keluarga, fasilitas kampus sebagai lembaga sekolah terkait pemenuhan kebutuhan budaya asal mahasiswa, dan kemampuan mahasiswa dalam beradaptasi dengan lingkungan barunya memiliki peran yang dapat mempengaruhi resiliensi mereka. Adapun budaya erat kaitannya dengan lingkungan, di mana seseorang yang tinggal di lingkungan dan budaya yang berbeda menunjukkan dirinya berstatus sebagai pendatang yang artinya intensitas dan frekuensi jumpa dengan keluarga dan komunitas/kelompok budaya sama pun akan berkurang. Berkurangnya interaksi tersebut, secara tidak langsung akan mengurangi sumber dukungan sosial dan dukungan keluarga yang sekaligus dapat mengurangi resiliensi mereka.

Pentingnya mempertimbangkan lingkungan dan budaya sebagai penentu resiliensi seseorang dikarenakan lingkungan dan budaya yang tepat dapat mendukung seseorang sekaligus mengubah perilaku seseorang yang juga berpengaruh pada resiliensi yang dihasilkan (Ungar, 2019). Seseorang yang terbiasa dengan lingkungan dan budaya tertentu selama belasan atau puluhan tahun langsung tinggal di lingkungan dan budaya baru, tentu mengharuskan dirinya untuk mampu beradaptasi dengan budaya baru setempat. Adaptasi antar budaya menuntut pendatang dan penduduk setempat untuk dapat memiliki keterbukaan, kekuatan, dan kemampuan berpikir positif agar tercapai adaptasi antar budaya yang maksimal (Utami, 2015). Sekalipun telah menetap di lingkungan dan budaya baru dalam kurun waktu lama, memungkinkan pendatang belum dapat beradaptasi dengan baik pada lingkungan dan budaya barunya, sehingga mereka dapat mengalami kesulitan bahkan dari hal mendasar seperti berinteraksi dengan orang baru. Baik secara bahasa, kebiasaan, maupun norma dan nilai dengan budaya setempat.

Mahasiswa keperawatan yang merupakan pendatang saat mengerjakan skripsi memungkinkan mengalami hambatan saat berinteraksi secara personal dengan dosen pembimbing yang memiliki budaya atau kebiasaan berbeda. Hal tersebut dapat menjadi tantangan yang sulit bagi mereka. Hal ini pun tidak menutup kemungkinan dosen pembimbing yang belum dapat terbuka dengan budaya mahasiswanya yang berbeda dari dirinya. Tidak sedikit juga mahasiswa yang berujung mengalami hambatan pengerjaan skripsi karena terhambat oleh komunikasi yang kurang baik dengan dosen pembimbing. Buruknya komunikasi mahasiswa keperawatan dengan dosen pembimbing saat mengerjakan skripsi akan menimbulkan stres, bahkan mahasiswa keperawatan akan cenderung tidak mau bertanya karena takut dengan kurang pengetahuannya akan pembuatan skripsi (Julianti \& Yulia, 2015). Tidak hanya 
mahasiswa kesulitan memahami apa yang hendak disampaikan dosen pembimbing, memungkinkan dosen atau mahasiswa terusik dengan penggunaan bahasa/ kalimat yang salah, sehingga menimbulkan salah paham dan suasana tegang.

Kesulitan saat menghadapi dosen pembimbing berkaitan dengan kemampuan mahasiswa keperawatan untuk beradaptasi, di mana mahasiswa keperawatan yang merupakan pendatang akan dituntut untuk bekerja lebih keras dalam menyesuaikan diri saat mengerjakan skripsi. Sama halnya dengan mahasiswa keperawatan yang mendapati dosen pembimbing yang berbeda latar belakang budaya dengan mereka, mengingat tidak semua dosen berasal dari lingkungan dan budaya yang sama dengan tempat kerjanya. Hal ini mengakibatkan mahasiswa selain menghadapi perubahan hidup dengan datangnya berbagai kesulitan saat mengerjakan skripsi, mereka juga harus mampu beradaptasi dengan budaya dan kebiasaan dosen pembimbing yang berbeda dengannya. Adapaun kemampuan beradaptasi atau menerima perubahan tersebut merupakan salah satu aspek yang menentukan resiliensi seseorang (Connor \& Davidson, 2003).

Dalam menghadapi kesulitan atau rintangan hidup, seseorang yang beragama atau berkeyakinan akan cenderung memohon atau meminta bantuan pada Tuhannya dan mengharapkan perubahan akan nasibnya menjadi lebih baik. Hal ini sebagai salah satu bentuk untuk meningkatkan resiliensi seseorang. Di mana pengaruh spiritual timbul akibat pengaruh kejiwaan berupa rohani dan batin. Dalam hal ini berupa kepercayaan pada Tuhan atau nasib yang dengan proses perenungan dan adaptasinya dalam menghadapi kesulitan akan memberikan pemikiran positif dan membangkitkan motivasi untuk mencari solusi (Connor \& Davidson, 2003). Hal itu pun dapat terjadi pada mahasiswa keperawatan yang sedang mengerjakan skripsi, di mana keterlibatan agama atau spiritualitas pada mahasiswa yang sedang mengerjakan skripsi menunjukkan hasil yang positif (Cahyani \& Akmal, 2017; Prihartono et al., 2018; Willda et al., 2016). Dengan demikian, mahasiswa keperawatan yang sedang mengerjakan dan menemui kesulitan dalam prosesnya sangat mungkin mengandalkan kepercayaan pada Tuhannya untuk merubah nasibnya lebih baik.

Pada status ekonomi, Diržytè, Rakauskienè, dan Servetkienè (2017) mendapatkan hasil bahwa kelompok yang berstatus ekonomi rendah secara signifikan memiliki resiliensi tiga kali lebih rendah dibandingkan kelompok yang berstatus ekonomi tinggi. Akan tetapi, kelompok yang berstatus ekonomi rendah dipercaya dapat melewati kesulitan yang didapat karena faktor ekonomi dengan bantuan resiliensi. Dengan demikian, status ekonomi pada mahasiswa juga seharusnya dapat memberikan pengaruh pada resiliensi yang dimiliki serta dapat membantu mereka dalam menghadapi kesulitan. Pada mahasiswa yang sedang mengerjakan skripsi, status ekonomi memungkinkan jadi faktor penghambat dalam pengerjaan skripsi itu sendiri. Hal ini dikarenakan dalam mengerjakan skripsi mahasiswa akan membutuhkan biaya penelitian yang tidak sedikit.

Karakteristik demografi lainnya adalah usia, seperti yang dijelaskan Bonanno et al. (2010) bahwa usia yang lebih tua menunjukkan resiliensi yang lebih tinggi. Hal ini menunjukkan bahwa ada pengaruh usia pada resiliensi seseorang. Adapun jika dilihat pada tahap perkembangan, usia mahasiswa tingkat akhir yang sedang mengerjakan skripsi dapat dikategorikan pada dewasa muda berdasarkan teori Erickson (1968). Pada tahap ini, salah satunya fase keintiman dengan lawan jenis sedang berkembang. Ada tidaknya keintiman dengan lawan jenis dapat ditunjukkan melalui status 
pernikahan mahasiswa. Hal ini pernah diteliti sebelumnya pada mahasiswa keperawatan tahun pertama. Namun, tidak didapatkan hasil berarti karena tidak ada mahasiswa yang sudah menikah (Prihartono et al., 2018). Adapun berdasarkan teori Santrock (2011), usia mahasiswa tingkat akhir dapat dikategorikan menjadi remaja akhir dan dewasa awal. Pada tahap ini, usia dewasa awal disebutkan akan lebih kompeten dalam pengambilan keputusan dibandingkan remaja akhir. Hal ini dikarenakan emosi orang yang lebih tua usianya lebih stabil dibandingkan yang lebih muda. Adapun pada mahasiswa, menurut Roellyana dan Listiyandini (2016), semakin matang usia mahasiswa, mahasiswa tersebut akan semakin terampil dalam melakukan pemecahan masalah. Selain itu, berhubungan dengan skripsi, semakin matang usia mahasiswa, semakin kuat keyakinannya bahwa dirinya mampu menyelesaikan skripsi disertai dengan rasa tanggung jawab untuk segera lulus (Roellyana \& Listiyandini, 2016).

Semua faktor demografi diatas
menunjukkan peran pentingnya dalam
menentukan resiliensi seseorang. Secara tidak langsung karakteristik demografi juga mempengaruhi resiliensi melalui aspek-aspek resiliensi. Dengan demikian, peningkatan resiliensi melalui faktor demografi dapat dijadikan salah satu acuan atau strategi dalam meningkatkan resiliensi mahasiswa keperawatan yang sedang mengerjakan skripsi guna meningkatkan angka keberhasilan mahasiswa dalam menyelesaikan skripsi tepat waktu. Tidak hanya sampai disana, tingginya hasil dari tingkat resiliensi yang didapat selama proses perkuliahan dan pengerjaan skripsi dapat memberi manfaat di masa mendatang. Di mana pengalaman postif dalam menghadapi kesulitan dapat memberi kontribusi yang baik untuk menghadapi kesulitan di masa mendatang (Southwick et al., 2014). Hal ini tentu bermanfaat bagi lulusan mahasiswa keperawatan, yang akan melanjutkan pendidikan profesi keperawatan yang beban studinya jauh lebih berat dari sekolah sarjana yang memungkinkan mereka dapat mengalami burnout yang lebih tinggi (Alimah, Swasti, \& Ekowati, 2016; Devi, Nursalam, \& Hidayati, 2013). Ditambah dengan menjadi perawat dikemudian hari memungkinan burnout yang dialami dapat lebih tinggi dibandingkan mahasiswa yang sedang melanjutkan pendidikan profesi keperawatan (Kholifah, Soeharto, \& Supriati, 2016).

Lebih jauh dari itu, mahasiswa profesi keperawatan yang lulus dengan resiliensi tinggi memungkinkan dapat lebih tahan pada stres yang timbul ditempat kerja seperti adanya kecemasan, depresi, stres traumatis sekunder, dan kelelahan (Rees, Breen, Cusack \& Hegney, 2015). Hal tersebut dikarenakan masalah yang mungkin ditemui ditempat kerja lebih sulit. Dengan demikian, memiliki bekal resiliensi yang tinggi sangat dibutuhkan calon perawat guna menghadapi beban kerja yang berlebihan, otonomi perawat yang rendah, intimidasi dan kekerasan, serta masalah organisasi yang mungkin ditemui di tempat kerja (Jackson, Firtko, \& Edenborough, 2007). Dalam membekali calon perawat dengan resiliensi yang tinggi dapat dilakukan saat mereka masih menempuh pendidikan sebagai mahasiswa, terutama saat mengerjakan skripsi. Hal tersebut dikarenkan mengerjakan skripsi memiliki tingkat kesulitan yang jauh lebih tinggi dibandingkan mata kuliah lain. Selain prosesnya yang lama, dalam mengerjakan skripsi pun mahasiswa harus mampu mengerjakannya secara mandiri terlepas dari berbagai kesulitan yang mungkin ditemui selama proses pengerjaan skripsi. Hal ini menjadikan pembentukan resiliensi yang tinggi dengan memperhatikan karakteristik demografi mahasiswa keperawatan saat masih sekolah sarjana dapat menjadi bekal yang bernilai tinggi untuk keberhasilan mereka di masa mendatang, sehingga lulusan yang tercetak tidak hanya pandai secara teori dan praktik tetapi juga 
pandai dalam mengelola masalah dan kuat dalam menghadapi berbagai kesulitan yang menjadikan mereka lebih resilien.

Dari uraian diatas, karakteristik demografi mahasiswa keperawatan yang sedang mengerjakan skripsi menjadi penting untuk diteliti. Penelitian ini bertujuan untuk melihat bagaimana hubungan karakteristik demografi terhadap resiliensi mahasiswa keperawatan yang sedang mengerjakan skripsi. Adapun karakteristik demografi yang akan diteliti dalam penelitian ini adalah usia, jenis kelamin, agama, budaya, status pernikahan, dan status ekonomi.

\section{Metode}

\section{Desain Penelitian}

Penelitian ini merupakan penelitian cross sectional dengan desain deskriptif korelasional. Penelitian ini dilakukan di kampus X di Jawa Barat, Indonesia pada bulan Maret sampai April 2019. Lokasi ini dipilih secara purposive (sengaja) dengan pertimbangan hasil studi pendahuluan dan merupakan salah satu kampus terbaik di Jawa Barat. Penelitian ini melibatkan seluruh mahasiswa keperawatan $X$ yang sedang mengerjakan skripsi. Kriteria inklusi partisipan merupakan mahasiswa tingkat akhir Fakultas Keperawatan $\mathrm{X}$ yang sedang mengerjakan skripsi minimal di semester delapan serta terdaftar sebagai mahasiswa aktif. Terdapat dua variabel dalam penelitian ini yaitu, karakteristik demografi sebagai variabel bebas dan resiliensi mahasiswa keperawatan yang sedang mengerjakan skripsi sebagai variabel terikat.

\section{Subjek}

Proses perekrutan sampel penelitian dilakukan di Fakultas Keperawatan X. Sebelum dilakukan perekrutan, didapatkan data dari Sub Bagian Akademik (SBA)
Fakultas Keperawatan $\mathrm{X}$ bahwa jumlah mahasiswa keperawatan $X$ yang sedang mengerjakan skripsi berjumlah 331 mahasiswa. Seluruhnya kemudian dihubungi untuk ditanyakan kesediaannya sebagai partisipan dalam penelitian ini. Setelah para mahasiswa dihubungi, didapatkan dua mahasiswa yang tidak lolos kriteria inklusi penelitian, yaitu satu mahasiswa sedang cuti akademik sehingga tidak masuk dalam kriteria sedang mengerjakan skripsi, serta satu mahasiswa berikutnya saat diklarifikasi ternyata telah mengundurkan diri sebagai mahasiswa Fakultas Keperawatan $X$. Dengan demikian, total sampel dan yang bersedia berpartisipasi dalam penelitian ini ada sebanyak 329 mahasiswa.

Adapun dalam pengumpulan data, tidak semua partisipan melakukan pengisian kuesioner dengan cara yang sama. Partisipan yang mudah ditemui, diberikan kuesioner dalam bentuk paper based questionnaire yaitu sebanyak 129 mahasiswa. Partisipan yang sulit ditemui dihubungi melalui media sosial (199 mahasiswa) dan surel (1 mahasiswa). Di mana lembar persetujuan menjadi partisipan dan pengisian kuesioner dilakukan secara online dengan memberikan tautan link yang berisi kuesioner untuk kemudian diisi sesuai ketersedian waktu yang dimiliki partisipan.

\section{Pengukuran dan Analisis Data}

Pengumpulan data menggunakan kuesioner berbentuk self-report. Dalam kuesioner penelitian terdapat lembar formulir data demografi dan lembar kuesioner resiliensi. Kuesioner resiliensi menggunakan kuesioner Connor Davidson Resilience Scale [CD-RISC] 25 ( $\alpha$ cronbach 0.89). Peneliti sudah mendapatkan izin penggunaan instrumen penelitian melalui korespondensi dengan Jonathan Davidson sebelum digunakan dalam penelitian ini. Kuesioner CD-RISC 25 terdiri dari 25 item pernyataan. Di dalamnya 
meliputi lima aspek resiliensi, yaitu 8 pernyataan mengenai aspek kompetensi personal, 7 pernyataan mengenai aspek percaya naluri sendiri, 5 pernyataan mengenai aspek menerima perubahan, 3 pernyataan mengenai aspek pengontrolan, dan 2 pernyataan mengenai pengaruh spiritual berupa keyakinan pada Tuhan atau nasib. Pilihan jawaban terdiri dari 5 pilihan, yaitu tidak setuju (0), kurang setuju (1), agak setuju (2), setuju (3), dan sangat setuju (4). Karakteristik demografi dalam penelitian ini adalah usia, jenis kelamin, agama, budaya, status pernikahan, dan status ekonomi. Adapun resiliensi dalam penelitian ini menunjukkan kemampuan mahasiswa keperawatan untuk menghadapi kesulitan, beradaptasi, dan mengatasi stres/ tekanan yang didapat saat mengerjakan skripsi. Setelah seluruh data terkumpul, data dikoding untuk kemudian dianalisis secara univariat.

Dari data demografi didapatkan, distribusi frekuensi dan persentase tiaptiap karakteristik demografi mahasiswa keperawatan $\mathrm{X}$ yang sedang mengerjakan skripsi. Adapun pada pengukuran resiliensi, setelah didapatkan skor total resiliensi mahasiswa keperawatan $\mathrm{X}$ yang sedang mengerjakan skripsi, skor tersebut kemudian dihitung secara statistik untuk didapatkan nilai rata-rata dan standar deviasi. Nilai tersebut digunakan untuk menghitung nilai kuartil yang akan membagi resiliensi mahasiswa keperawatan $\mathrm{X}$ yang sedang mengerjakan skripsi kedalam tiga kelompok, yaitu tingkat resiliensi tinggi, tingkat resiliensi sedang, dan tingkat resiliensi rendah.

Setelah didapatkan data skor resiliensi total, tahap tersebut kemudian dilakukan pada tiap-tiap karakteristik demografi untuk melihat distribusi frekuensi dan persentase resiliensi berdasarkan subkategori dari tiaptiap karakteristik demografi. Secara detail data tersebut ditunjukkan pada Tabel 1.
Untuk mengetahui ada tidaknya hubungan karakteristik demografi dengan resiliensi mahasiswa keperawatan $X$ yang sedang mengerjakan skripsi, peneliti menggunakan uji korelasi dari chi-square dengan menggunakan aplikasi statistik komputer. Secara detail, hasil analisis data tersebut dapat dilihat pada Tabel 2 .

\section{Hasil}

Berdasarkan data demografi, didapatkan distribusi frekuensi dan persentase tiaptiap karakteristik demografi mahasiswa keperawatan $\mathrm{X}$ yang sedang mengerjakan skripsi. Adapun pada pengukuran resiliensi, setelah didapatkan skor total resiliensi mahasiswa keperawatan $X$ yang sedang mengerjakan skripsi, skor tersebut kemudian dihitung secara statistik untuk didapatkan nilai rata-rata dan standar deviasi. Nilai tersebut digunakan untuk menghitung nilai kuartil yang akan membagi resiliensi mahasiswa keperawatan $\mathrm{X}$ yang sedang mengerjakan skripsi kedalam tiga kelompok, yaitu tingkat resiliensi tinggi, tingkat resiliensi sedang, dan tingkat resiliensi rendah.

Setelah didapatkan data skor resiliensi total, tahapan yang sudah dilakukan kemudian diaplikasikan pada tiap-tiap karakteristik demografi untuk melihat distribusi frekuensi dan persentase resiliensi berdasarkan subkategori dari tiap-tiap karakteristik demografi. Secara detail data tersebut ditunjukkan pada Tabel 1. Untuk mengetahui ada tidaknya hubungan karakteristik demografi dengan resiliensi mahasiswa keperawatan $X$ yang sedang mengerjakan skripsi, peneliti menggunakan uji korelasi dari chi-square dengan menggunakan aplikasi statistik komputer. Secara detail, hasil analisis data tersebut dapat dilihat pada Tabel 2. 
Tabel 1. Resiliensi Mahasiswa Keperawatan $X$ yang Sedang Mengerjakan Skripsi Berdasarkan Karakteristik Demografi

\begin{tabular}{|c|c|c|c|c|c|c|c|c|c|c|}
\hline \multirow{3}{*}{ Karakteristik } & \multirow{3}{*}{$\mathbf{n}$} & \multirow{3}{*}{ f } & \multicolumn{6}{|c|}{ Resiliensi } & \multirow{3}{*}{ Mean } & \multirow{3}{*}{ SD } \\
\hline & & & \multicolumn{2}{|c|}{ Tinggi } & \multicolumn{2}{|c|}{ Sedang } & \multicolumn{2}{|c|}{ Rendah } & & \\
\hline & & & f & $\%$ & f & $\%$ & $f$ & $\%$ & & \\
\hline \multicolumn{11}{|l|}{ Usia } \\
\hline Remaja Akhir (18-21 tahun) & 156 & 47.4 & 18 & 11.5 & 109 & 69.9 & 29 & 18.6 & 69.08 & 12.134 \\
\hline Dewasa Awal (>21 tahun) & 173 & 52.6 & 34 & 19.7 & 103 & 59.5 & 36 & 20.8 & 70.12 & 13.162 \\
\hline Total & 329 & 100 & 52 & 15.8 & 212 & 64.4 & 65 & 19.8 & 69.63 & 12.677 \\
\hline \multicolumn{11}{|l|}{ Jenis Kelamin } \\
\hline Perempuan & 253 & 76.9 & 36 & 14.2 & 165 & 65.2 & 52 & 20.6 & 68.98 & 12.642 \\
\hline Laki-laki & 76 & 23.1 & 16 & 21.1 & 47 & 61.8 & 13 & 17.1 & 71.78 & 12.639 \\
\hline Total & 329 & 100 & 52 & 15.8 & 212 & 64.4 & 65 & 19.8 & 69.63 & 12.677 \\
\hline \multicolumn{11}{|l|}{ Agama } \\
\hline Islam & 318 & 96.7 & 49 & 15.4 & 204 & 64.2 & 65 & 20.4 & 69.42 & 12.716 \\
\hline Kristen & 11 & 3.3 & 3 & 27.3 & 8 & 72.7 & & & 75.45 & 10.328 \\
\hline Total & 329 & 100 & 52 & 15.8 & 212 & 64.4 & 65 & 19.8 & 69.63 & 12.677 \\
\hline \multicolumn{11}{|l|}{ Budaya } \\
\hline Jawa Barat (Sunda) & 256 & 77.8 & 38 & 14.8 & 170 & 66.4 & 38 & 14.8 & 69.89 & 12.340 \\
\hline $\begin{array}{l}\text { Luar Jawa Barat (Bukan } \\
\text { Sunda) }\end{array}$ & 73 & 22.2 & 14 & 19.2 & 42 & 57.5 & 17 & 23.3 & 68.70 & 13.843 \\
\hline Total & 329 & 100 & 52 & 15.8 & 212 & 64.4 & 65 & 19.8 & 69.63 & 12.677 \\
\hline \multicolumn{11}{|l|}{ Status Ekonomi } \\
\hline Rendah (<Rp1.668.372) & 111 & 33.7 & 12 & 10.8 & 68 & 61.3 & 31 & 27.9 & 66.82 & 12.344 \\
\hline Tinggi (>Rp1.668.371) & 218 & 66.3 & 40 & 18.3 & 144 & 66.1 & 34 & 15.6 & 71.06 & 12.633 \\
\hline Total & 329 & 100 & 52 & 15.8 & 212 & 64.4 & 65 & 19.8 & 69.63 & 12.677 \\
\hline \multicolumn{11}{|l|}{ Status Pernikahan } \\
\hline Menikah & 17 & 5.2 & 2 & 11.8 & 13 & 76.5 & 2 & 11.8 & 69.00 & 13.444 \\
\hline Belum Menikah & 312 & 94.8 & 50 & 16.0 & 199 & 63.8 & 63 & 20.2 & 69.66 & 12.656 \\
\hline Total & 329 & 100 & 52 & 15.8 & 212 & 64.4 & 65 & 19.8 & 69.63 & 12.677 \\
\hline
\end{tabular}

Dari data yang ditunjukkan pada Tabel 1 , didapatkan bahwa mahasiswa keperawatan $X$ yang sedang mengerjakan skripsi memiliki mayoritas resiliensi sedang yang terjadi pada remaja akhir (18-21 tahun) sebanyak 109 mahasiswa $(69.9 \%)$; perempuan sebanyak 165 mahasiswa (65.2\%); beragama Islam sebanyak 204 mahasiswa (64.2\%); berasal dari Jawa Barat dengan budaya
Sunda sebanyak 170 mahasiswa $(66.4 \%)$; berstatus ekonomi tinggi sebanyak 144 mahasiswa (66.1\%); dan belum menikah sebanyak 199 mahasiswa (63.8\%). Tidak seluruhnya menunjukkan resiliensi yang lebih tinggi sekalipun jumlah mayoritas pada subkategorinya lebih banyak seperti yang ditunjukkan pada tiga karakteristik pertama yaitu, usia, jenis kelamin, dan agama. 
Tabel 2. Hasil Analisis Bivariat Karakteristik Demografi dengan Resiliensi

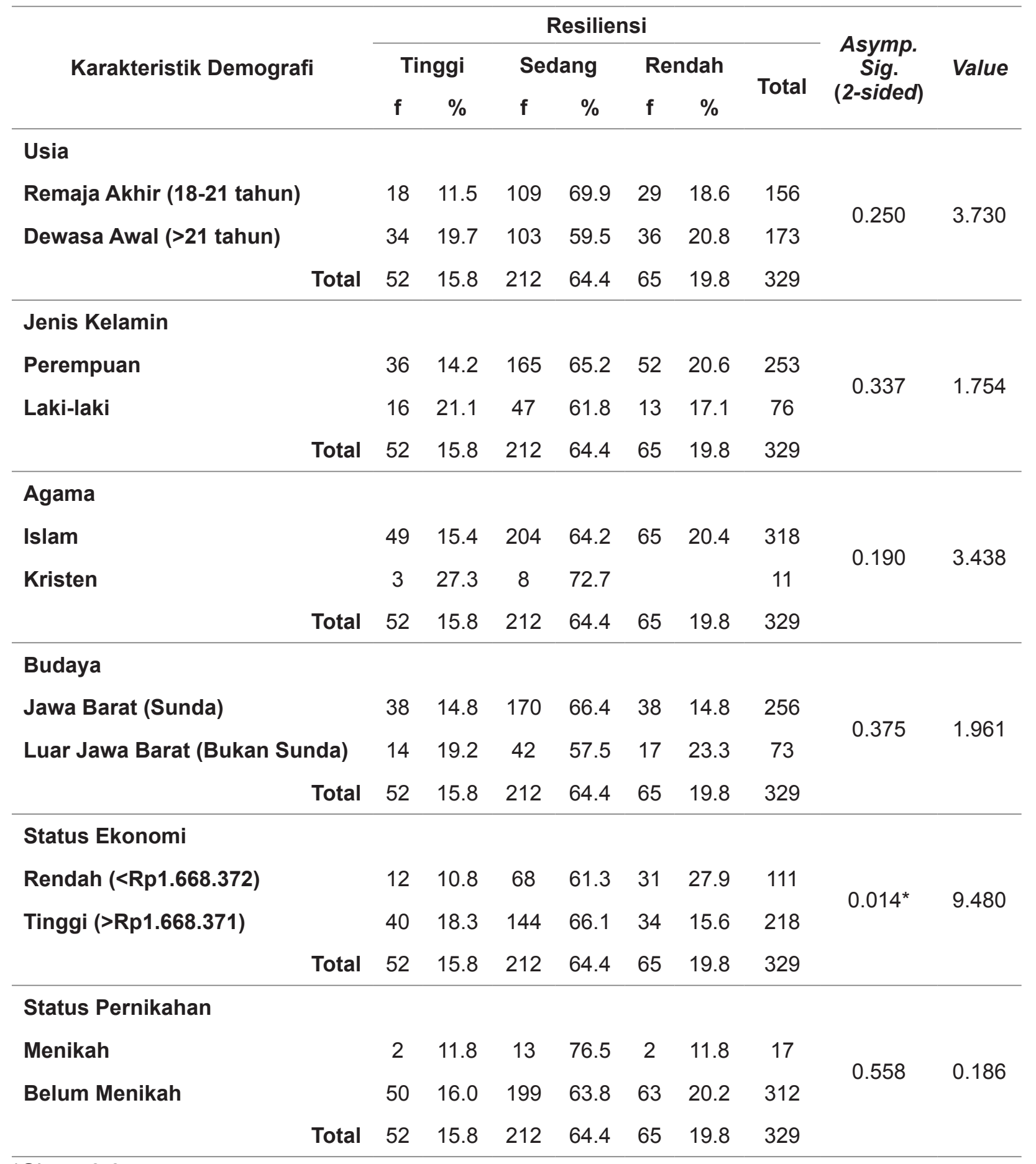

${ }^{*} \operatorname{Sig} p<0.05$

Pada Tabel 2 ditunjukkan karakteristik demografi yang memiliki hubungan dengan resiliensi mahasiswa keperawatan $X$ yang sedang mengerjakan skripsi adalah status ekonomi. Di mana didapatkan nilai asymptotic significance (2-sided) $[\rho]<0.05$. Artinya, ada hubungan yang bermakna antara status ekonomi dengan resiliensi mahasiswa keperawatan $X$ yang sedang mengerjakan skripsi $(\rho=0.014)$. Hal ini diperkuat dengan nilai chi square hitung yang lebih besar dari nilai chi square tabel. Di mana derajat bebas (df) $=2$, maka nilai chi square tabelnya adalah sebesar 5.9915. Karena nilai chi square hitung $9.480>$ nilai chi square table 5.991, 
maka dapat disimpulkan ada hubungan antara karakteristik demografi status ekonomi dengan resiliensi mahasiswa keperawatan $X$ yang sedang mengerjakan skripsi. Adapun pada karakteristik demografi lainnya hanya merupakan suatu kebetulan karena nilai $\rho<$ $\alpha$ dan nilai chi square hitung < nilai chi square table. Sehingga, dapat disimpulkan tidak terdapat hubungan.

\section{Pembahasan}

Tujuan dari penelitian ini adalah mengidentifikasi karakteristik demografi yang berhubungan dengan resiliensi pada mahasiswa yang sedang mengerjakan skripsi. Peneliti ingin melihat apakah ada hubungan yang signifikan antara karakteristik demografi dengan resiliensi mahasiswa keperawatan $X$ yang sedang mengerjakan skripsi. Karakteristik demografi yang diteliti dalam penelitian ini adalah usia, jenis kelamin, agama, budaya, status pernikahan, dan status ekonomi. Adapun karakteristik demografi yang menunjukkan adanya hubungan yang signifakan adalah status ekonomi. Artinya, hasil yang didapat memiliki makna dan bukan suatu kebetulan, yaitu mahasiswa keperawatan $X$ yang sedang mengerjakan skripsi dengan status ekonomi tinggi lebih resilien dibandingkan mahasiswa keperawatan $X$ yang berstatus ekonomi rendah. Di mana semakin tinggi penghasilan/pendapatan orang tua mahasiswa keperawatan $\mathrm{X}$, resiliensi yang ditunjukkan mahasiswa keperawatan $\mathrm{X}$ juga akan semakin tinggi.

Tingginya resiliensi pada mahasiswa keperawatan $X$ yang sedang mengerjakan skripsi dengan status ekonomi tinggi, dapat disebabkan karena segala kebutuhan penelitian dan skripsinya dapat dipenuhi dengan keadaan finansial keluarga yang baik. Beda halnya dengan mahasiswa keperawatan $X$ yang sedang mengerjakan skripsi dengan status ekonomi rendah, untuk memenuhi kebutuhan sehari-hari pun dapat dikatakan masih sulit. Akibatnya, untuk memenuhi kebutuhan dan biaya yang diperlukan untuk penelitian dan skripsi akan terhambat. Alhasil, baik secara langsung maupun tidak langsung, kondisi ekonomi yang kurang menunjang dapat menghambat mahasiswa untuk mengerjakan penelitian dan skripsi itu sendiri. Di mana sebagian partisipan terutama pada mahasiswa yang memiliki status ekonomi rendah selain mengerjakan skripsi juga bekerja. Sedangkan waktu yang digunakan untuk bekerja akan mengurangi waktu mahasiswa untuk mengerjakan skripsi. Akibatnya, beban yang dirasakan mahasiswa keperawatan $X$ yang sedang mengerjakan skripsi dengan ekonomi rendah dan bekerja akan lebih berat dibandingkan mahasiswa yang berkecukupan secara ekonomi.

Tidak hanya menghambat pengerjaan skripsi, hasil penelitian juga menunjukkan adanya hubungan yang signifikan antara status ekonomi dengan resiliensi mahasiswa keperawatan $X$ yang sedang mengerjakan skripsi. Artinya, semakin tinggi pendapatan/ penghasilan keluarga mahasiswa keperawa$\tan \mathrm{X}$, resiliensi mahasiswa keperawatan $X$ yang sedang mengerjakan skripsi akan semakin meningkat. Hal ini didukung penelitian Diržytė et al. (2017) yang mendapatkan hasil resiliensi kelompok yang berstatus ekonomi rendah tiga kali lebih rendah daripada yang berstatus ekonomi tinggi. Sehingga, selain menghambat proses pengerjaan skripsi, status ekonomi yang rendah juga secara signifikan dapat menurunkan resiliensi mahasiswa keperewatan $X$ yang sedang mengerjakan skripsi.

Berdasarkan karakteristik usia, dapat digambarkan bahwa mahasiswa dewasa awal keperawatan $X$ yang sedang mengerjakan skripsi lebih resilien dibandingkan yang remaja akhir. Hal ini serupa dengan dijelaskan Bonanno et al. (2010), bahwa usia yang lebih tua lebih resilien dibandingkan yang lebih muda. Tidak hanya itu, usia yang lebih tua juga menunjukkan mereka lebih kompeten 
dalam menentukan pemecahan masalah dan solusi. Hal ini didukung penelitian Roellyana dan Listiyandini (2016) bahwa semakin matang usia mahasiswa tingkat akhir, maka mahasiswa tersebut akan semakin terampil dalam melakukan pemecahan masalah skripsinya. Selain itu, juga disebutkan bahwa semakin matang usia mahasiswa tingkat akhir, mahasiswa tersebut juga akan semakin memiliki rasa tanggung jawab untuk segera lulus. Adapun pada remaja akhir, mereka sedang dalam tahap yang rentan dan mudah bingung, serta cenderung memiliki emosi yang tidak stabil, dan mudah meledak-ledak dalam kondisi tidak tenang (Santrock, 2011). Hal ini dapat terjadi pada mahasiswa remaja akhir yang menemui kesulitan dalam mengerjakan skripsi sehingga dapat menjadi salah satu penyebab resiliensi remaja akhir lebih rendah dibandingkan yang dewasa awal.

Karakteristik demografi selanjutnya adalah agama. Tingginya resiliensi pada mahasiswa Kristen keperawatan $X$ yang sedang mengerjakan skripsi, dapat disebabkan seluruh mahasiswa Kristen di Fakultas Keperawatan $X$ tergabung dalam suatu perkumpulan yaitu Persekutuan Mahasiswa Kristen Katolik (PMKK) Fakultas Keperawatan X. Perkumpulan ini, dapat disebut sebagai suatu komunitas yang terdiri dari mahasiswa beragama Kristen di Fakultas Keperawatan X. Komunitas ini dapat membantu meningkatkan resiliensi mahasiswa keperawatan $X$ yang sedang mengerjakan skripsi dalam sisi keagamaan. Tidak hanya itu, dengan komunitas tersebut, akan terbentuk suatu hubungan kekeluargaan yang secara efektif dapat memberikan dukungan pada sesamanya, termasuk pada mahasiswa yang sedang mengerjakan skripsi. Di mana dukungan sosial dan memiliki hubungan yang aman dengan orang lain dapat membantu meningkatkan resiliensi seseorang (Connor \& Davidson, 2003). Hal ini didukung penelitian Sari dan Indrawati (2016) yang mendapatkan hasil adanya hubungan yang signifikan antara dukungan sosial dari teman dengan resiliensi mahasiswa.

Berbeda dengan yang mahasiswa Islam keperawatan $X$ yang sedang mengerjakan skripsi, tidak semua mahasiswa Islam di Fakultas Keperawatan $\mathrm{X}$ tergabung dalam suatu perkumpulan yaitu Rohis Fakultas Keperawatan X. Hanya 43 partisipan dalam penelitian ini yang pernah bergabung dalam perkumpulan tersebut. Dikatakan pernah, karena pada perkumpulan ini setiap tahun baik pengurus dan anggota perkumpulan tersebut terus berubah, dan tidak semua yang pada tahun sebelumnya tergabung ikut serta kembali pada tahun berikutnya. Adapun pada tahun 2019 sudah tidak ada partisipan dalam penelitian ini yang aktif sebagai pengurus ataupun anggota perkumpulan tersebut. Hal tersebut, dapat menjadi salah satu penyebab mahasiswa Islam keperawatan X yang sedang mengerjakan skripsi memiliki mayoritas yang beresiliensi rendah.

Padahal, ketika mengalami peristiwa buruk, menghadapi masa penuh stres ataupun gangguan berlebih, spiritualitas/ agama memiliki peran penting sebagai bagian inti pada resiliensi seseorang (Greene et al., 2004). Hal ini pun didukung penelitian Cahyani dan Akmal (2017) yang mendapatkan hasil bahwa terdapat peran signifikan spiritualitas terhadap resiliensi pada mahasiswa yang sedang mengerjakan skripsi. Berikut, penelitian Willda dkk. (2016) yang mendapatkan hasil bahwa agama dapat memberikan arahan pada mahasiswa yang sedang mengerjakan skripsi dan meyakinkan mereka bahwa Tuhan dapat membantu, serta memberikan ketenangan saat mengerjakan skripsi. Sehingga, mahasiswa yang sedang mengerjakan skripsi tidak akan mudah gelisah atau panik. Hal ini sejalan dengan penelitian Prihartono dkk. (2018) yang mendapatkan hasil bahwa pengaruh spiritual yang tinggi dapat membantu mahasiswa ketika buntu atau tidak memiliki pemecahan masalah yang jelas. Di mana keyakinan atau kepercayaan 
seseorang dapat mempengaruhi resiliensi (Connor \& Davidson, 2003). Sehingga, adanya perkumpulan keagamaan yang dapat meningkatkan spiritualitas sekaligus memberikan dukungan sosial pada mahasiswa keperawatan yang sedang mengerjakan skripsi menjadi penting, karena dapat membantu meningkatkan resiliensi yang juga berguna untuk menghadapi kesulitan selama mengerjakan skripsi.

Karakteristik demografi berikutnya adalah budaya. Lebih tingginya rata-rata resiliensi mahasiswa keperawatan $X$ yang sedang mengerjakan skripsi dan berasal dari Jawa Barat dapat dikarenakan mereka sudah terbiasa dengan budaya Sunda dari kecil. Hal ini didukung penelitian Amelia dkk. (2014), yang mendapatkan hasil bahwa mahasiswa yang berasal dari kota yang sama dengan kampus memiliki resiliensi yang lebih tinggi dibandingkan yang merantau. Selain itu, mereka yang tinggal di Jawa Barat memiliki akses jumpa dengan keluarga yang lebih mudah, sehingga intensitas pertemuan dan dukungan keluarga yang didapat pun lebih baik. Di mana memiliki hubungan yang baik dengan keluarga dan memiliki keluarga yang suportif terbukti mempengaruhi resiliensi (Connor \& Davidson, 2003; Greene et al., 2004) dan dapat meningkatkan resiliensi pada mahasiswa (Mufidah, 2017). Hal ini tentu tidak didapatkan mahasiswa keperawatan $\mathrm{X}$ yang sedang mengerjakan skipsi dan berasal dari luar Jawa Barat dengan budaya bukan Sunda. Akan tetapi, banyaknya dari mereka yang beresiliensi tinggi dapat disebabkan adanya dukungan dari teman dengan budaya yang sama.

Teman sebudaya tersebut dapat ditemui mahasiswa keperawatan $\mathrm{X}$ di komunitas yang ada dikampusnya yang disebut dengan paguyuban. Paguyuban ini memfasilitasi seluruh mahasiswa di kampus tersebut untuk bertemu, berteman, dan membangun suatu ikatan kekeluargaan dengan teman paguyubannya dan tidak terkecuali juga pada mahasiswa keperawatan $X$ yang sedang mengerjakan skripsi. Tidak hanya sebagai teman, dengan memiliki hubungan yang aman, mereka dapat menjadi sumber dukungan (Connor \& Davidson, 2003; Sari \& Indrawati, 2016) serta mengajarkan cara yang digunakannya untuk beradaptasi dengan lingkungan. Hal ini pun didukung penelitian Mufidah (2017) bahwa mahasiswa yang berasal dari budaya berbeda dengan lokasi tinggalnya memiliki resiliensi yang lebih baik ketika memiliki kualitas hubungan yang baik dengan komunitas di mana mahasiswa tersebut tinggal. Dengan demikian, adanya paguyuban/komunitas budaya di kampus tersebut menjadi penting bagi mahasiswa keperawatan $\mathrm{X}$ yang sedang mengerjakan skripsi yang berasal dari luar Jawa Barat. Selain menjadi keluarga kedua, ikatan dan dukungan yang didapat, serta kesepahaman latar belakang budaya yang sama dapat menjadi sumber kekuatan untuk menghadapi kesulitan selama mengerjakan skripsi.

Karakteristik demografi berikutnya adalah jenis kelamin. Berdasarkan data temuan, didapatkan resiliensi mahasiswa laki-laki keperawatan $\mathrm{X}$ yang sedang mengerjakan skripsi lebih tinggi dibandingkan perempuan. Lebih tingginya resiliensi laki-laki sejalan dengan penelitian Amelia dkk. (2014), Azzahra (2017), serta Roellyana dan Listiyandini (2016) yang juga mendapatkan hasil bahwa resiliensi laki-laki lebih tinggi dibandingkan perempuan. Hal ini, menurut Roellyana dan Listiyandini (2016) dapat terjadi karena lakilaki memiliki kemampuan yang lebih baik dibandingkan perempuan untuk mengatasi kesulitan-kesulitan yang ada pada proses pengerjaan skripsi. Adapun menurut Amelia dkk. (2014), laki-laki lebih resilien karena kemampuannya dalam beradaptasi lebih baik daripada perempuan. Sedangkan menurut Azzahra (2017), tingginya resiliensi laki-laki dikarenakan rendahnya distres psikologis yang dialami. Berbeda dengan perempuan yang lebih ekspresif sehingga memiliki distres 
psikologis tinggi yang dapat menurunkan resiliensi. Sehingga, dapat dikatakan lakilaki memiliki nilai toleransi yang lebih baik terhadap kesulitan dibandingkan perempuan.

Karakteristik terakhir yaitu status pernikahan. Berdasarakan nilai rata-rata resiliensi dari status pernikahan mahasiswa keperawatan X (lihat Tabel 1), ditunjukkan adanya keunggulan baik yang sudah dan belum menikah. Artinya, mahasiswa keperawatan $X$ yang sudah menikah, pasangannya sudah memberikan peran yang cukup untuk mendukung mereka dalam mengerjakan skripsi. Hal ini didukung dengan teori perkembangan Erickson (1968), di mana mereka sedang dalam fase berkembangnya keintiman dengan lawan jenis. Hubungan tersebut, memungkinkan mahasiswa yang sudah menikah juga mendapatkan dukungan dari pasangannya untuk mengerjakan skripsi. Namun, hal ini hanya dapat terjadi jika pasangan memberi dukungan yang positif pada pengerjaan skripsi. Sebalikanya, pasangan yang tidak mendukung akan menghambat mereka dalam mengerjakan skripsi dan dapat menjadi indikasi adanya hubungan yang kurang baik. Padahal, memiliki hubungan yang baik dengan orang lain (Connor \& Davidson, 2003) termasuk keluarga, dapat mempengaruhi resiliensi seseorang. Sehingga, hubungan yang kurang baik dengan pasangan juga dapat menurunkan resiliensi mahasiswa keperawatan $X$ yang sedang mengerjakan skripsi dan sudah menikah. Diluar peran pasangan, mahasiswa keperawatan $X$ yang sudah menikah memiliki kemampuan yang cukup untuk membagi antara kepentingan keluarga dan akademik.

Pada mahasiswa keperawatan $X$ yang sedang mengerjakan skripsi yang belum menikah, dapat dikatakan sudah mendapatkan dukungan yang cukup dari orang lain untuk memotivasi mereka dalam mengerjakan skripsi. Dukungan tersebut bisa didapatkan dari teman, keluarga, dosen wali, maupun dosen pembimbing (Greene et al., 2004; Krisdianto \& Mulyanti, 2015; Mufidah, 2017; Sari \& Indrawati, 2016). Di mana, kurangnya motivasi dapat menghambat mereka dalam mengerjakan skripsi (Asmawan, 2016). Sehingga, baik mahasiswa yang sudah menikah atau belum menikah, kesuksesan dalam mengerjakan skripsi dapat bergantung pada bagaimana dia menjalin hubungan dan beradaptasi dengan orang terdekatnya. Di mana menurut Southwick et al. (2014), seseorang yang dapat beradaptasi baik dalam kehidupan pribadi, mungkin gagal beradaptasi di lingkungan akademik, dan sebaliknya. Namun, juga memungkinan seseorang dapat beradaptasi dengan baik atau gagal dalam beberapa hal sekaligus, seperti dalam akademik dan berkeluarga.

Secara keseluruhan, karakteristik demografi yang meliputi usia, jenis kelamin, agama, budaya, status ekonomi, dan status pernikahan menunjukkan tingkatan resiliensi yang bervariasi pada mahasiswa keperawatan yang sedang mengerjakan skripsi. Hal ini menunjukkan karakteristik demografi dapat mempengaruhi resiliensi baik secara langsung dan tidak langsung melalui aspek-aspek resiliensi. Adapun karakteristik demografi yang berhubungan signifikan adalah status ekonomi sedangkan karakteristik lain tidak berhubungan signifikan. Selain dapat dikarenakan jumlah sampel yang tidak seimbang/merata pada kelompok subkategorinya, hal ini juga dapat dikarenakan perbedaan sistem belajar blok pada mahasiswa keperawatan $X$ yang sedang mengerjakan skripsi, lamanya waktu yang sedang ditempuh untuk mengerjakan skripsi, dan berbagai faktor lain yang tidak diteliti dalam penelitian ini termasuk kemungkinan kesalahan peneliti dalam menganalisis data penelitian. Dalam penelitian ini tentu ada keterbatasan. Di mana jumlah sampel pada beberapa karakteristik demografi menunjukkan jumlah sampel yang tidak seimbang/merata sehingga salah satu 
kelompok pada subkategorinya menunjukkan jumlah mahasiswa yang terlalu banyak/ sedikit. Hal ini dapat memberikan hasil yang bias pada ada tidaknya hubungan dengan resiliensi mahasiswa keperawatan $X$ yang sedang mengerjakan skripsi.

\section{Kesimpulan}

Disamping ada keterbatasan penelitian, penelitian ini menunjukkan bahwa resiliensi mahasiswa keperawatan $X$ yang sedang mengerjakan skripsi berhubungan signifikan dengan karakteristik demografi status ekonomi. Sedangkan, pada karaktarestik demografi usia, jenis kelamin, budaya, agama, dan status pernikahan tidak menunjukkan hubungan yang signifikan. Adapun berdasarkan rata-rata karakteristik resiliensi, rata-rata yang lebih tinggi terjadi pada kategori dewasa awal, laki-laki, beragama Kristen, berasal dari Jawa Barat dengan budaya Sunda, berstatus ekonomi tinggi, dan belum menikah.

Implikasi dari hasil penelitian adalah untuk mencegah keterlambatan mahasiswa keperawatan dalam mengerjakan skripsi tepat waktu, perlu adanya pendampingan yang baik dari dosen pembimbing dan dosen wali, dukungan dari teman dan keluarga, kegiatan keagamaan, serta komunitas dengan latar belakang budaya yang sama. Hal ini dapat membantu meningkatkan resiliensi dan membantu mahasiswa keperawatan menghadapi kesulitan-kesulitan dalam mengerjakan skripsi. Diharapkan pada penelitian selanjutnya dapat dilakukan penelitian serupa dengan jumlah pembanding yang lebih merata antar subkategori, sehingga hasil temuan dapat lebih menggambarkan data dalam hal perbandingan jumlah. Hal ini terkait dengan keterbatasan penelitian di mana terdapat jumlah yang tidak seimbang pada beberapa kategori. Penelitian selanjutnya juga diharapkan dapat mengukur sejauh mana pengaruh karakteristik demografi pada tingkatan resiliensi seseorang.

\section{Daftar Pustaka}

Agung, G., \& Budiani, M. S. (2013). Hubungan kecerdasan emosi dan self efficacy dengan tingkat stres mahasiswa yang sedang mengerjakan skripsi. Character, 01(02).

Alimah, S., Swasti, K. G., \& Ekowati, W. (2016). Gambaran burnout pada mahasiswa keperawatan di Purwokerto. Jurnal Keperawatan Soedirman, 11(2), 130-141.

Amelia, S., Asni, E., \& Chairilsyah, D. (2014). Gambaran ketangguhan diri (resiliensi) pada mahasiswa tahun pertama fakultas kedokteran Universitas Riau. Jom FK, 1(2), 1-9.

Asmawan, M. C. (2016). Analisis kesulitan mahasiswa menyelesaikan skripsi. Jurnal Pendidikan IImu Sosial, 26(2), 51-57.

Aziz, A., \& Rahardjo, P. (2013). Faktorfaktor prokrastinasi akademik pada mahasiswa tingkatakhir yang menyusun skripsi di Universitas Muhammadiyah Purwokerto tahun akademik 2011/2012. Psycho Idea, 11(01), 61-68.

Azzahra, F. (2017). Pengaruh resiliensi terhadap distres psikologis pada mahasiswa. Jurnal IImiah Psikologi Terapan, 05(01), 80-96.

Bonanno, G. A., Westphal, M., \& Mancini, A. D. (2010). Resilience to Loss and Potential Trauma. Annual Review of Clinical Psychology, 7(1), 511535.https://doi.org/10.1146/annurevclinpsy-032210-104526

Cahyani, Y.E., \&Akmal, S.Z. (2017). Peranana spiritualitas terhadap resiliensi pada mahasiwa yang sedang mengerjakan skripsi. Jurnal Psikoislamedia, 2(1), 32-41.

Connor, K. M., \& Davidson, J. R. T. (2003). Development of a new resilience scale: The Connor-Davidson Resilience Scale (CD-RISC). Depression and Anxiety, 18(2), 76-82. https://doi.org/10.1002/ 
da. 10113

Devi, H. M., Nursalam, \& Hidayati, L. (2013). Burnout syndrom mahasiswa profesi ners berdasarkan analisis faktor stressor, relational meaning dan coping strategy. Jurnal Ners, 8(2), 175-182.

Diržytè, A., Rakauskienè, O. G., \& Servetkienè, V. (2017). Evaluation of resilience impact on socio-economic inequality. International Journal of Entrepreneurship and Sustainability Issues, 4(4), 489-501. https://doi.org/ http://doi.org/10.9770/jesi.2017.4.4(7) Publisher

Erickson, E. H. (1968). Identity: Youth and Crisis. W. W. Norton. New York.

Greene, R. R., Galambos, C., \& Lee, Y. (2004). Resilience theory. Journal of Human Behavior in the Social Environment, 8(4), 75-91. https://doi.org/10.1300/ $\mathrm{J} 137 \mathrm{v} 08 \mathrm{n} 04 \quad 05$

Holaday, M., \& McPhearson, R. W. (1997). Resilience and Severe Burns. Journal of Counseling \& Development, 75(5), 346-356. https:// doi.org/10.1002/j.1556-6676.1997. tb02350.x

Jackson, D., Firtko, A., \& Edenborough, M. (2007). Personal resilience as a strategy for surviving and thriving in the face of workplace adversity: a literature review. Journal of Advanced Nursing, 60(1), 1-9. https://doi.org/10.1111/j.13652648.2007.04412.x

Julianti, R., \& Yulia, A. (2015). Hubungan komunikasi antara mahasiswa dan dosen pembimbing skripsi dengan stres dalam menyusun skripsi pada mahasiswa S1 Keperawatan STIKES Ranah Minang Tahun 2015. Jurnal IImiah IImu Pendidikan, XV(2), 57-62.

Kholifah, S., Soeharto, S., \& Supriati, L. (2016). Hubungan faktor-faktor internal dengan kejadian kelelahan mental (burnout) pada perawat. Jurnal Kesehatan Mesencephalon, 2(4), 251259.
Krisdianto, M. A., \& Mulyanti. (2015). Mekanisme koping berhubungan dengan tingkat depresi pada mahasiswa tingkat akhir. Jurnal Ners dan Kebidanan Indonesia, 3(2), 71-76.

Mufidah, A. C. (2017). Hubungan antara dukungan sosial terhadap resiliensi pada mahasiswa bidikmisi dengan mediasi efikasi diri. Jurnal Sains Psikologi, 6(2), 68-74.

Prihartono, M. N., Sutini, T., \& Widianti, E. (2018). Gambaran resiliensi mahasiswa tahun pertama program a2016 Fakultas Keperawatan Universitas Padjadjaran. Jurnal Keperawatan BSI, 6(1), 96-104.

Rees, C. S., Breen, L. J., Cusack, L., \& Hegney, D. (2015). Understanding individual resilience in the workplace: The international collaboration of workforce resilience model. Frontiers in Psychology, 6(73), 1-7. https://doi. org/10.3389/fpsyg.2015.00073

Roellyana, S., \& Listiyandini, R. A. (2016). Peranan optimisme terhadap resiliensi pada mahasiswa tingkat akhir yang mengerjakan skripsi. In Prosiding Konferensi Nasional Peneliti Muda Psikologi Indonesia (Vol. 1, hal. 29-37). Jakarta: Fakultas Psikologi Universitas YARSI.

Santrock, J. W. (2011). Life-Span Development (13 ed.). New York: McGraw-Hill.

Sari, P. K. P., \& Indrawati, E. S. (2016). Hubungan antara dukungan sosial teman sebaya dengan resiliensi akademik pada mahasiswa tingkat akhir jurusan $\mathrm{x}$ fakultas teknik Universitas Diponegoro. Jurnal Empati, 5(2), 177182.

Southwick, S. M., Bonanno, G. A., Masten, A. S., PanterBrick, C., \& Yehuda, R. (2014). Resilience definitions, theory, and challenges: interdisciplinary perspectives. European Journal of Psychotraumatology, 5(1). https://doi.org/10.3402/ejpt. v5.25338 
Ungar, M. (2019). Designing resilience research: Using multiple methods to investigate risk exposure, promotive and protective processes, and contextually relevant outcomes for children and youth. Child Abuse \& Neglect, 96, 1-8. https://doi.org/10.1016/j.chiabu. 2019.104098

Utami, L. S. S. (2015). Teori-teori adaptasi antar budaya. Jurnal Komunikasi, 7(2), 180-197.

Willda, T., Nazriati, E., \& Firdaus. (2016). Hubungan resiliensi diri terhadap tingkat stres pada dokter muda fakultas kedokteran Universitas Riau. Jom FK, 3(1), 1-9.

Windle, G. (2011). What is resilience? A review and concept analysis. In Reviews in Clinical Gerontology (Vol. 21, hal. 152-169). UK. https://doi.org/10.1017/ $\underline{\mathrm{S} 0959259810000420}$

Yulia, P. C., Afrianti, H., \& Octaviani, V. (2015). Pengaruh Komunikasi interpersonal mahasiswa dan dosen pembimbing skripsi terhadap gejala stress mahasiswa dalam menyusun skripsi. Jurnal Professional FIS UNIVED, 2(1), 61-69. 